\title{
Magyarország országképe és a turizmusbiztonsággal kapcsolatos attitúdök empirikus vizsgálata 2018-ban
}

\author{
Szerző: Rácz Attila
}

A turizmus alapvetóen bizalmi iparág, komplex rendszerének egyik legfontosabb alapja a biztonság. A biztonság problematikája rendkivül sokrétû, a természeti katasztrófáktól a pénzügyi folyamatokon és a terrorizmuson át egészen a szálláshely-szolgáltatás, a környezet, az élelmiszerek, az egészség vagy a közlekedés biztonságáig terjed. A turizmus rendszerében minden biztonságot befolyásoló tényezó hat az utazási döntésre is, így egy-egy desztináció meghatározó elemei a prekoncepció és a tapasztalat. Jelen tanulmány célja annak bemutatása, hogy a biztonságérzettel kapcsolatos prekoncepciók és tapasztalatok miként alakultak Magyarországgal kapcsolatban a hazai rendezvények résztvevóinek körében.

Kulcsszavak: turizmusbiztonság, rendezvények, desztináció, fesztiválok, biztonság.

\section{Bevezetés, célkitúzés}

A turizmus rendszerében minden biztonságot befolyásoló tényezô hat az utazási döntésre is, 1́gy egy-egy desztináció meghatározó elemei a prekoncepció és a tapasztalat. A prekoncepcióhoz sorolhatók mindazon tényezôk, amelyek először nem valós tapasztalás útján realizálódnak, hanem valakik vagy valami által közvetve jutnak el a fejekbe. Tipikusan ilyenek a politikai környezetről, a közlekedés biztonságáról, a természeti környezet biztonságáról és a terrorfenyegetettségről elérhető információk (WILK 2017). Az utazások során elsősorban a minden szempontból biztonságos desztinációt igyekszünk kiválasztani, másodsorban az érdeklődésünknek megfelelő szórakozási lehetőséget, illetve rendezvényhelyszínt.

$\mathrm{Az}$ elmúlt évek során Európában elkövetett terrorcselekmények kapcsán arra lehetett számítani, hogy a béke iparága, a turizmus, radikális visszaesést mutat majd az öreg kontinensen, fóleg azokban az országokban és városokban, ahol ilyen jellegú események történtek. A bekövetkezett biztonságpolitikai változások nemcsak a turizmusban dolgozó szakembereket és az utazni vágyókat, hanem a rendfenntartó erôket is új kihívások elé állították és állítják ma is (BESENYÓ 2017a). Az általános rendvédelmi feladatok mellett napjaink új rendészeti kihívásai közé tartozik a terrorveszély elhárítása a turisztikai desztinációkban és a kiemelt rendezvényeken. A kihívást tovább fokozza,

\footnotetext{
kutató, MTÜ Kutatási és ágazati képzési igazgatóság; egyetemi adjunktus Szegedi Tudományegyetem, Attila.Racz@mtu.gov.hu
}

hogy a rendészeti feladatokat folyamatosan fenn kell tartani, hiszen a desztinációválasztás egyik kulcsfontosságú tényezője a biztonságérzet, vagy inkább a biztonságos desztináció képének megléte a turisták tudatában ${ }^{2}$. A desztinációk biztonságáról kialakult kép meghatározza az utazási döntést (PÉTER et al. 2018). A kérdés, hogy a kényszerú és sokszor jól látható biztonsági intézkedések milyen érzéseket keltenek a turistákban? BOROS (2017) a biztonságos közterek megteremtéséról értekezik tanulmányában.

Napjainkban az egyik legfontosabb tényező, akár egy ország közbiztonságáról, akár egy szolgáltatásról legyen szó, a bizalom. Egy turisztikai szolgáltatónak már azt figyelembe kell vennie, hogy a megbízhatósági, biztonsági tényezők feltérképezése a majdani vendégkör részéről már az érkezés előtt, az utazás tervezésekor megkezdődik, a foglalás pillanatában lép a második fázisba, az utazás közben megváltozhat a biztonságérzet, és csak annak végére realizálódik és rögzül. Ahhoz, hogy egy turisztikai szolgáltatóról pozitív kép és az ezzel járó jó biztonságérzet alakuljon ki, ahhoz a térségnek, a fogadó országnak is garantálnia kell a teljeskörú biztonságot a társadalom, a környezet, a politika és a gazdaság számos szegmesében az érkezéstől a távozásig.

\footnotetext{
${ }^{2}$ Becslések szerint 2018 decemberében Franciaországban körülbelül 2025\%-kal kevesebb foglalás történt a „sárgamellényes” tüntetések kapcsán kialakult zavargások miatt. „A hatás háromszoros: rövid távú lemondások, a foglalások lassulása, majd Franciaország mint turisztikai desztináció imázsára gyakorolt hatás", összegzi Jean-Virgile Crance, a szállodaláncok nemzeti szövetségének elnöke (Mercure, Ibis, Sofitel, Balladins, Kyriad stb.). Forrás: https://www.tourism-review.com/french-tourism-hitby-the-demonstrations-news10883, Letöltve: 2019. január 10.
} 
Jelen tanulmány célja annak bemutatása, hogyan értékelik a magyarországi rendezvények résztvevői az olyan biztonságérzetet befolyásoló tényezóket, mint:

- a közlekedésbiztonság,

- az élelmiszerbiztonság,

- a programok, attrakciók és szolgáltatások biztonsága,

- valamint a társadalmi stabilitás (erőszakmentesség, terrorizmus fenyegetettség).

\section{Módszertan}

Jelen tanulmány több kutatási módszer alkalmazására épít. Az elemzés során hazai és nemzetközi adatbázisokat használtunk fel az úgynevezett desk research szakaszban, amikor az adatok másodelemzését végeztük. A kutatás field research része kvalitatív és kvantitatív adatfelvételi technikák ötvözésére alapozott módszertannal készült, melynek lényege, hogy a kvantitatív szakaszban alkalmazott mérőeszköz (kérdőív) elkészítése előtt a kutatási témában kvalitatív adatfelvételek (megfigyelés, interjúk, fókuszcsoportok) is készülnek szakértőkkel ${ }^{3}$, valamint az adott terepen ${ }^{4}$. Ennek az a legfőbb előnye, hogy a kvantitatív mérőeszköz elkészítésekor pontosabban lehet konceptualizálni és operacionalizálni, így az eredmények érvényessége is jobb lesz (BRYMAN 2015).

A kvantitatív kutatás során alkalmazott, CAPI technikával végzett kérdőíves adatfelvétel során 1968 fó került megkérdezésre, melyből 504 interjú készült a Sziget Fesztiválon, 107 interjú a budapesti augusztus 20-i ünnepségen, 268 interjú a Mesterségek Ünnepén, 273 interjú a Szegedi Ifjúsági Napokon (SZIN), 281 interjú a Soproni Szüreti Napokon, 273 interjú a Hősök terén és végül 262 interjú a Vásárcsarnokban. A külföldi és magyar válaszadók aránya - a KSH vendégforgalmi statisztikájához igazított kvóta alkalmazásával - a 40-60 arányt hozza, 40,3\% külföldi és 59,7\% magyar válaszadó. Az egyes helyszínek látogatottsága eltérô volt a magyar-külföldi dimenzióban és a demográfiai jellemzők tekintetében is, ezért a mintavétel során ehhez igazítottuk a kvótát, így az egyes helyszíneknél eltérő arányok figyelhetők meg.

\footnotetext{
${ }^{3}$ A kvalitatív adatfelvételi részben mintegy 10 interjú készült rendőrségi szakértőkkel, valamint fesztiválokon dolgozó biztonsági személyzet tagjaival. A biztonsági személyzet tagjaival készült interjúkat a Magyar Turisztikai Ügynökség megbízásából a Századvég Alapítvány végezte.

${ }^{4}$ Résztvevő megfigyelést végeztünk a Mesterségek Ünnepén 2018. augusztus 17-19 között.

${ }^{5}$ A kvantitatív adatfelvételt a Magyar Turisztikai Ügynökség megbízásából a Századvég Alapítvány végezte 2018. július-szeptember hónapokban.
}

\section{Európa és Magyarország helyzete a biztonságos desztinăciók rangsoraban}

Európa a legfrissebb adatok alapján még mindig a világ legbékésebb földrajzi régiójának számít. 2019 januárjában az SOS International és a Control Risks által közzétett Travel Risk Map biztonsági kockázatbecsléseinek eredményei ${ }^{6}$ azt mutatják, hogy az utazók teljes biztonságban érezhetik magukat a világ néhány országában, melyek mindegyike Európában található. A térkép szerint a Dániában, Finnországban, Grönlandon, Izlandon, Luxemburgban, Norvégiában, Szlovéniában és Svájcban történô utazás során jelentkező biztonsági kockázat nem releváns.

Hasonló eredményeket mutat az Institute for Economics rangsora is, amely egy több komponensből számított indexérték alapján készül, és a Global Peace Index (GPI) nevet viseli. Ezen index alapján 2018 első félévében az első 10 között 6 európai ország szerepel. A rangsor élén az előzó évhez hasonlóan továbbra is Izland áll, Magyarország a 17.?

Az elmúlt két évtized adataiból (UNWTO 2017a) jól kirajzolódik, hogy a geopolitikai helyzet, a bekövetkező események, valamint a különbözô helyzetkezelési módok (marketing kampányok, biztonsági intézkedések) külön-külön és együttesen is jelentős hatást gyakorolnak az adott terület turizmusára. Azokban az országokban, ahol az elmúlt időszakban erőszakos cselekmények (például terrortámadás, zavargások) történtek, ott mind az odalátogató turisták száma, mind a turizmusból származó bevételek drasztikusan csökkentek (WORLD ECONOMIC FORUM 2015).

2015-ról 2016-ra az Európába látogató turisták száma ugyan növekedett, de ebben az időszakban ez a növekedés mindössze már csak $2 \%$, míg az előzó évi (2014-2015) időszakban 5\% volt. A NyugatEurópába látogató turisták száma 2015-2016 között összességében ugyan nem változott (1. ábra), azonban Franciaországba 5\%-kal, Belgiumba pedig 14\%-kal látogattak kevesebben kimondottan biztonsági okokból. ${ }^{8}$

\footnotetext{
${ }^{6}$ https://www.travelriskmap.com/\#/planner/map/security, Letöltve: 2019. január 10.

${ }^{7} \mathrm{http} / / /$ visionofhumanity.org/app/uploads/2018/06/Global-Peace-Index-2018-2.pdf, Letöltve: 2018. február 10.

${ }^{8}$ Hasonló helyzet alakult ki Izraelben, amikor 2016 novemberében palesztin radikálisok tudatosan több helyen felgyújtották a nemzeti parkokat, valamint a nagyobb városokat körülvevő rekreációs, és turisztikai célokat szolgáló erdőket. A több napon keresztül tartó tűzvész nem csak akkor, de később is éreztette negatív hatását, amit az országba látogató turisták számán is le lehetett mérni (BESENYÖ 2017b).
} 
A nemzetközi turistaérkezések számának változása 2015-2017. augusztus (\%-ban az elôzố év azonos idôszakához viszonyítva)

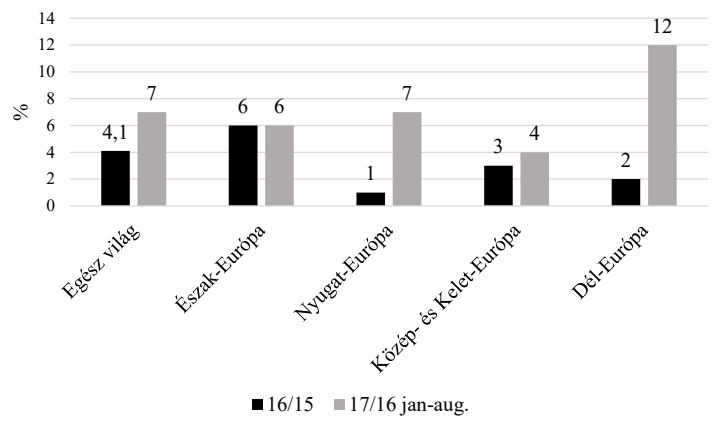

Forrás: UNWTO (2017b)

2015-2016 között az európai turizmus gyengülése mellett a turisztikai desztinációk regionális átrendeződése is megfigyelhető volt. Míg korábban inkább Európa nyugati és északi országainak a látogatottsága növekedett, 2016-ra a biztonságosabbnak tekintett Közép- és Kelet-Európa 3, majd 2017 első nyolc hónapjában 4 százalékponttal megelőzte Nyugat-Európát az odalátogató külföldi turisták számának növekedésében. Az európai biztonsági intézkedések hatására 2016-ra javulni kezdett Nyugat-Európa helyzete. A 2016-2017. január-augusztusi adatok alapján (UNWTO 2017b) az látható, hogy Nyugat-Európa ekkorra visszanyerte korábbi vonzerejét a külföldi turisták körében, ugyanakkor Közép- és Kelet-Európa megtartotta, majd tovább fokozta növekedési értékét 2017-ben 5, 2018 első félévében 7 százalékponttal (2. ábra) (UNWTO 2018).

2. ábra

\section{A nemzetközi turistaérkezések számának változása 2016-2018. elsô félév (\%-ban az előzó év azonos időszakához viszonyítva)}

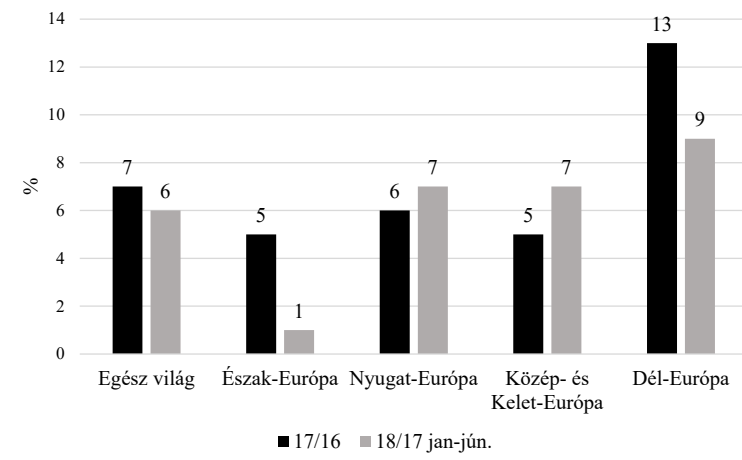

Forrás: UNWTO (2017b)
Az elmúlt évek biztonságérzetet befolyásoló eseményei és a válaszreakcióként meghozott rendelkezések hatásaiból látszik, hogy a turizmusban a biztonság egyértelmúen versenyelőnyt jelent. Azokba az országokba, amelyek biztonságos desztinációként jelennek meg a küldő országok lakosságának mentális térképén, több turista érkezik, és ott több vendégéjszakát tölt el, amely több bevételt jelent.

\section{Kutatási eredmények}

\subsection{A DESZTINÁCIÓ KIVÁLASZTÁSÁNAK SZEMPONTJAI - BIZTONSÁG, MINT SZEMPONT}

Kutatásunk fó fókuszpontja mellett - mely alapvetôen a turizmus és biztonság témaköre volt - azt is vizsgáltuk, hogy a magyarországi rendezvényekre érkező turisták ${ }^{9}$ milyen főbb szempontok alapján választják ki utazásaik helyszínét, és mik azok a meghatározó tényezők - a desztinációválasztásról bővebben DUDÁS és szerzőtársainak (2017) tanulmányában olvashatunk -, amelyek szerepet játszanak egy-egy ország kiválasztásánál (PUSZTAI 2013). Az erre vonatkozó kérdéseket a kérdőívben nyitott kérdésként tettük fel, és a kapott válaszokat tartalomelemzést követően kategorizálva értékeltük. A válaszok alapján elmondhatjuk, hogy 2018-ban a biztonság még mindig a TOP 10 desztinációválasztási szempont között szerepel, azonban egyre inkább előtérbe kerülnek azok a hagyományos értékek, mint a kultúra, a történelem, a látnivalók, valamint az ár és a gasztronómia (3. ábra).

A külföldi válaszadók jóval nagyobb arányban említették a kultúra, a programok és a történelem szempontokat, míg az ár - bár fontos szempont, de - háttérbe szorult olyan tényezók mögött, mint az étkezés, az ételek, valamint a látnivalók és az időjárás.

Az egy évvel korábbi, 2017-es, 8 országban készült fókuszcsoportos vizsgálatok ${ }^{10}$ eredményei hasonló szempontokat emeltek ki a desztinációválasztást illetôen, azonban a biztonság - amelynek megítélése rendkívül eseményérzékeny - ebben az évben még hangsúlyosabb volt (1. táblázat).

\footnotetext{
${ }^{9}$ A minta nem tekinthető reprezentatívnak a Magyarországra érkező öszszes turista alapsokaságra nézve, mivel az adatfelvétel nagyobbrészt rendezvény helyszíneken történt.

${ }^{10}$ MTÜ Országimázs kutatás 2017. A felmérést a Magyart Turisztikai Ügynökség megbízásából a Kantar Millward Brown végezte 8 országban (Ausztria, Csehország, Franciaország, Olaszország, Lengyelország, Németország, Svédország, Egyesült Királyság) 2017-ben.
} 
Múhely

A desztinációválasztás fóbb szempontjai 2018-ban TOP 25 említés - összesen három megnevezésnél $(\mathrm{db})$

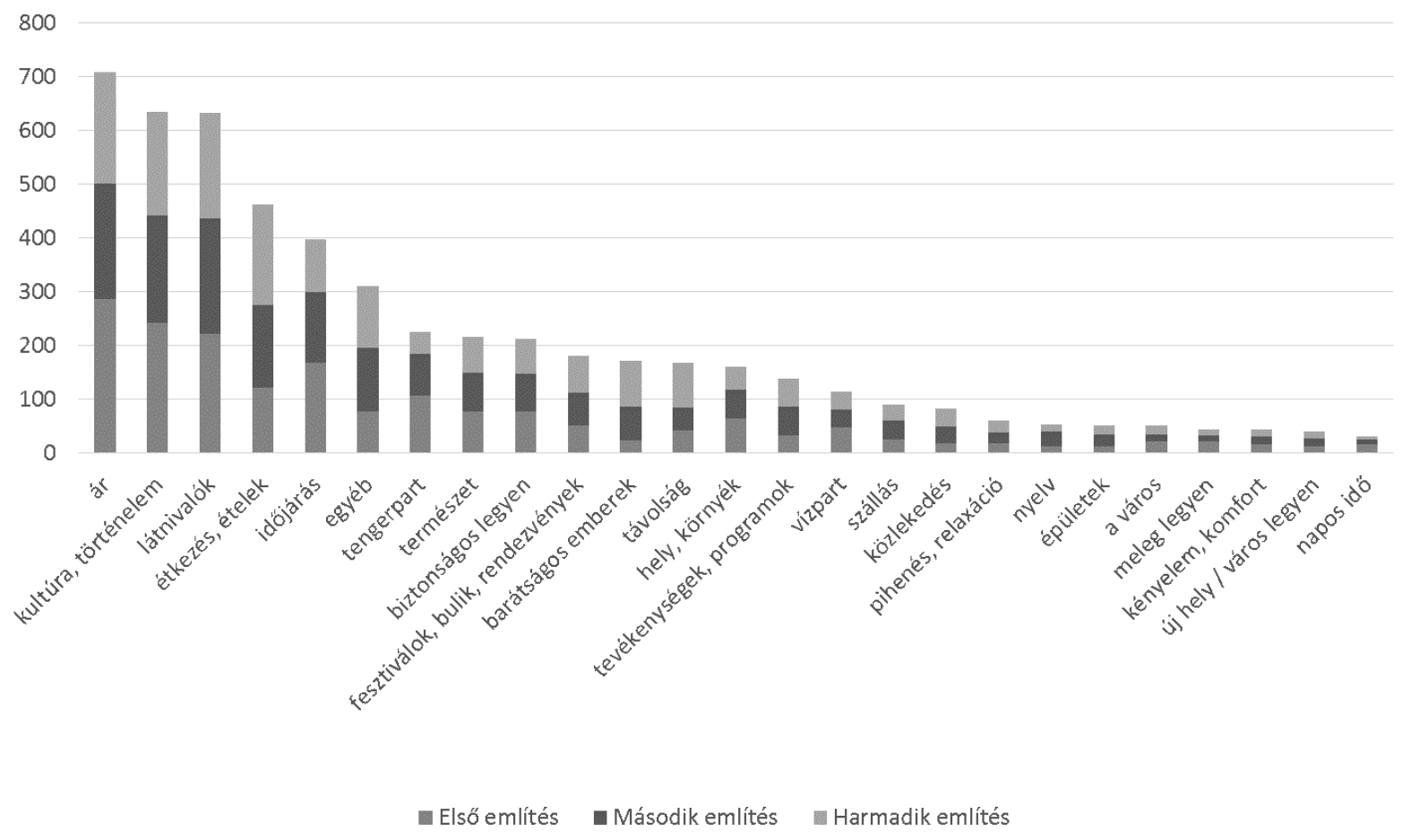

Forrás: saját szerkesztés, MTÜ-Századvég kutatás (2018) alapján

A desztinációválasztás fóbb szempontjai 2017-ben

1. táblázat

\begin{tabular}{|c|c|c|}
\hline Legtöbb országnál megjelenő szempont & $\begin{array}{c}\text { Több országnál megjelenő } \\
\text { szempont }\end{array}$ & $\begin{array}{l}\text { Egyes országoknál } \\
\text { megjelenő szempont }\end{array}$ \\
\hline Ár/érték: utazás, szállás, szolgáltatások & Van-e tengerpart & $\begin{array}{l}\text { Emberi jogok tiszteletben } \\
\text { tartása (S) }\end{array}$ \\
\hline $\begin{array}{l}\text { Látnivalók sokasága és változatossága: például építészet, } \\
\text { kultúra, táj }\end{array}$ & Infrastruktúra & Tisztaság $(A)$ \\
\hline $\begin{array}{l}\text { Változatos tevékenységek kinálata, például wellness, aktív } \\
\text { turizmus lehetôsége }\end{array}$ & Vendégszeretet & Presztizs $(G, F)$ \\
\hline $\begin{array}{l}\text { Idôjárás: általában melegebb idôjárást keresnek, télen pedig } \\
\text { a sípályákat }\end{array}$ & Éjszakai élet & $\begin{array}{l}\text { Jó és olcsó repülő összeköttetés } \\
\text { (UK) }\end{array}$ \\
\hline Gasztronómia & Idôtöltés gyerekeknek & $\begin{array}{l}\text { Utak állapota (I: szeretnek } \\
\text { autóval utazni) }\end{array}$ \\
\hline Megközelithetôség/távolság & Nem túlzottan felkapott & Vásárlási lehetôségek (S) \\
\hline \multicolumn{3}{|l|}{ Nyelvismeret } \\
\hline Biztonság/politikai stabilitás & WOM, barátok ajánlása & \\
\hline
\end{tabular}

Forrás: MTÜ Országimázs kutatás 2017 
A két egymást követó évben végzett vizsgálataink eredményei megerósítik azokat a nemzetközi statisztikákra alapozott hipotéziseket, amelyek azt feltételezik, hogy Európában a terrortámadásokat követô emelt szintú biztonsági intézkedések hatására a turistaforgalom újra a korábbi szintre állt vissza, és növekvó tendenciát mutat.

A 2018-as adatfelvétel során a megkérdezetteknek az utazás tervezésekor fóbb szerepet játszó szempontok megnevezése után azt is meg kellett adni, hogy egy-egy adott szemponthoz melyik országot választanák utazási célul, ezáltal nemcsak a desztinációválasztás kulcstényezőit ismerhettük meg, hanem a hozzájuk társított potenciális országok körét is (2. táblázat). ${ }^{11}$

2. táblázat

Desztinációválasztási szempontokhoz társított országok (az egyes szempontoknál történt említési gyakoriság \%-ban)

\begin{tabular}{|c|c|c|c|c|c|c|c|c|c|c|c|c|}
\hline Ország & ऽ્ & 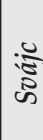 & 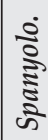 & $\begin{array}{c}\dot{0} \\
\hat{\tilde{D}} \\
0\end{array}$ & $\frac{0}{3}$ & 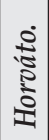 & 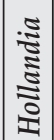 & $\begin{array}{c}0 \\
: 0 \\
: 00 \\
: 0\end{array}$ & 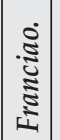 & 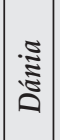 & 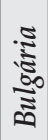 & 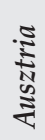 \\
\hline Fesztiválok & & & 18 & & 29 & & 7 & & & & & \\
\hline Biztonság & & 11 & & & 26 & 5 & & 4 & & 6 & & 8 \\
\hline Ár & & & & 5 & 23 & 12 & & 6 & & & 4 & 6 \\
\hline Ételek & & & & 31 & 14 & & & 6 & 8 & & & \\
\hline Látnivalók & & & 6 & 18 & 13 & & & & 12 & & 5 & \\
\hline Természet & 5 & & & 5 & 13 & & & & & & & 8 \\
\hline \begin{tabular}{|l|} 
Ku l t ú $r a$, \\
történelem
\end{tabular} & & & & 19 & 12 & & & 6 & 11 & 4 & & \\
\hline Időjárás & & & 21 & 12 & 5 & & & 12 & & & & \\
\hline
\end{tabular}

Forrás: saját számítás, MTÜ-Századvég kutatás (2018) alapján

Magyarország a fesztiválok ${ }^{12}$, a biztonság, az ár és a természet említése esetén listavezetó az országok között. A fesztiválok turizmusáról és gazdasági hatásairól részletesen JÁSZBERÉNYI (2016) könyvében olvashatunk. Az időjárás, az ételek, a látni-

\footnotetext{
${ }^{11} \mathrm{Az}$ egyes szempontoknál minden esetben nagy arányban szerepelt az egyéb kategória (minden szempontnál közel 40\%), a válaszok az országok között nagyon elaprózódtak, ezért minden egyes szempontnál csak a legtöbbször említett 4-5 országot emeltük ki.

${ }^{12}$ A fesztiválok Magyarországhoz való nagyarányú társítása a minta sajátosságából adódhat, mégpedig annak okán, hogy a válaszadók nagyobb része a fesztiválok látogatói közül került ki. A minta nagysága 1968 fó volt, melyből 504 interjú készült a Sziget Fesztiválon, 107 interjú a budapesti augusztus 20-i ünnepségen, 268 interjú a Mesterségek Ünnepén 273 interjú a Szegedi Ifjúsági Napokon (SZIN), 281 interjú a Soproni Szüreti Napokon, 273 interjú a budapesti Hősök terén és végül 262 interjú a budapesti Vásárcsarnokban.
}

valók és a kultúra kapcsán a legtöbben elsősorban a mediterrán országokat említették (Olaszország, Spanyolország), de ezen szempontok említésekor hazánk is az elsők között található.

\subsection{TURIZMUS ÉS BIZTONSÁG}

A turizmus rendszerében minden biztonságot befolyásoló tényezô egyben az utazási döntést befolyásoló tényezó is, így egy-egy desztináció kiválasztásának meghatározó elemei a prekoncepció és a tapasztalat (MICHALKÓ 2007). A világ számos országában az instabil politikai helyzet, a terrortámadások veszélye vagy a magas búnözési ráta kiszámíthatatlan kockázatot jelent az utazók biztonságára nézve (BAYRAMOV-AGÁRDI 2018). A 2018-as adatok alapján Magyarország a legtöbb európai országgal együtt mindhárom kockázati tényezố tekintetében az alacsony veszélyességi kategóriában helyezkedik el. ${ }^{13}$

$\mathrm{Az}$ általunk végzett kutatás hasonló eredményeket mutat. Az általános értelemben vett biztonságos úticél kiválasztásának mérlegelésekor a legtöbbeknek Magyarország (26\%) után - amely eredmény, mivel a magyarországi rendezvényeken résztvevốk körében készült, valószínúleg az ország pozitív megítélésének irányába torzít - Svájc (11\%), Ausztria $(8 \%)$, továbbá Dánia (6\%), Horvátország (5\%) és Görögország (4\%) jutott az eszébe. A válaszok fennmaradó $40 \%$-ának esetében a válaszok erősen szóródtak.

Az Európai Unió biztonságának az elmúlt 5-10 évben történt alakulásával kapcsolatban megoszlanak a vélemények. A legtöbben (29\%) úgy vélekednek, hogy ugyanolyan biztonságos, mint korábban volt, és a „kevésbé biztonságos" és „,valamivel biztonságosabb" válaszokat is közel ugyanannyian jelölték meg, $22 \%$, illetve $20 \%$. A megkérdezettek $7 \%$-a szerint "sokkal rosszabb a biztonság, mint korábban”, és a minta 12\%-a jelölte meg, hogy ",sokkal biztonságosabb Európa, mint korábban".

A rendezvények látogatóinak véleménye között statisztikailag is igazolható összefüggés figyelhető meg: leginkább a Soproni Szüreti Napok (13,5\%) és a budapesti augusztus 20-i ünnepség közönsége $(13,1 \%)$ gondolja úgy, hogy Európa biztonsága az elmúlt öt évben sokat romlott. A két csoport között nagy különbség, hogy míg az „inkább rosszabb a biztonság" választ az augusztus 20-i ünnepség körében kevesen jelölték meg $(17,8 \%)$, addig a soproni válaszadók esetében ennek a válasznak a megjelölése messze a legmagasabb arányú volt (34,5\%). Vagyis a Soproni Szüreti Napok közönsége volt az

\footnotetext{
${ }^{13} \mathrm{https}: / / \mathrm{www}$. independent.co.uk/travel/news-and-advice/travel-risk-map2019-worlds-safest-dangerous-countries-to-visit-iran-uk-slovenia-denmark-a8644646.html
} 
az alminta, ahol kiemelkedő volt a rosszabb biztonság megjelölése, összesen 48\%. Hasonlóan magas volt a szegedi SZIN közönségének körében a „kevésbé biztonságos Európában utazni” válasz megjelölése (28,9\%). A helyszínek közötti eltérés az eltérő közönségnek és magyar-külföldi aránynak, illetve annak köszönhető, hogy a Sziget Fesztiválon inkább fiatalabbak vesznek részt, míg a Soproni Szüreti Napokon idősebbek, valamint családok. Az Európai Unió biztonságára vonatkozó kérdésnél szignifikáns összefüggés mutatható ki a korral, mint változóval. Minél idősebb valaki, annál inkább gondolja azt, hogy rosszabb lett a biztonság az elmúlt 5-10 évben. A valamivel biztonságosabb és sokkal biztonságosabb válaszok együttes aránya a 18-20 évesek körében 35,9\% volt, míg a 45 év felettieknél csak $20 \%$.

Jelentős eltérés volt megfigyelhető a magyar-külföldi bontásban is. A külföldiek 46,3\%-a véli úgy, hogy Európa biztonságosabb lett (4-es és 5-ös válasz összevonva), míg a magyaroknak csupán 21,7\%-a. A kérdéskör folytatásában arra is rákérdeztünk, hogy Magyarország mennyire tekinthető biztonságos országnak más európai uniós országokhoz képest a turisták számára. Az itt kapott válaszoknál már nem a normál eloszlás figyelhetô meg, a válaszok az inkább biztonságos felé tolódtak el. A kevésbé biztonságos két válaszlehetőséget összesen 10\% jelölte meg. Az „ugyan- annyira biztonságos" választ a megkérdezettek 39\%-a adta meg, ezzel ez a legtöbbek által megjelölt válaszlehetőség. $28 \%$ szerint valamivel biztonságosabb ország, míg 18\% szerint sokkal biztonságosabb.

Statisztikailag is igazolható összefüggés mutatható ki a külföldi és a magyar rendezvénylátogatók attitûdjei között. A magyar válaszadók biztonságosabb országnak gondolják Magyarországot, mint a külföldiek. Míg a rendezvények magyar vendégeinek egy ötöde (20,2\%) vélekedett úgy, hogy Magyarország sokkal biztonságosabb ország, mint az EU többi országa, addig a külföldieknél ez 14\%. A magyarok 31,7\%-a véli úgy, hogy valamivel biztonságosabb ország Magyarország, míg a külföldieknek 22,4\%-a. A megkérdezettek kora szerint is jelentôs eltérések figyelhetôk meg, a fiatalok kisebb arányban gondolják, hogy Magyarország biztonságosabb, mint más uniós ország, míg az idősebbek nagyobb arányban. A két válasz - inkább biztonságosabb és sokkal biztonságosabb együttes megoszlása a 18-20 éveseknél 37,4\%, míg a 45 év felettieknél 63,5\%.

Kutatásunk során arról is megkérdeztük válaszadóinkat, hogy a közelmúltban Európában történt terrorcselekmények mennyire befolyásolják a turisztikai utazási célok kiválasztásában. A válaszok alapján az látható, hogy a válaszadók egyharmadát 2018-ban már egyáltalán nem befolyásolják

\section{A turizmusbiztonság tényezóinek értékelése - összes említés (\%)}

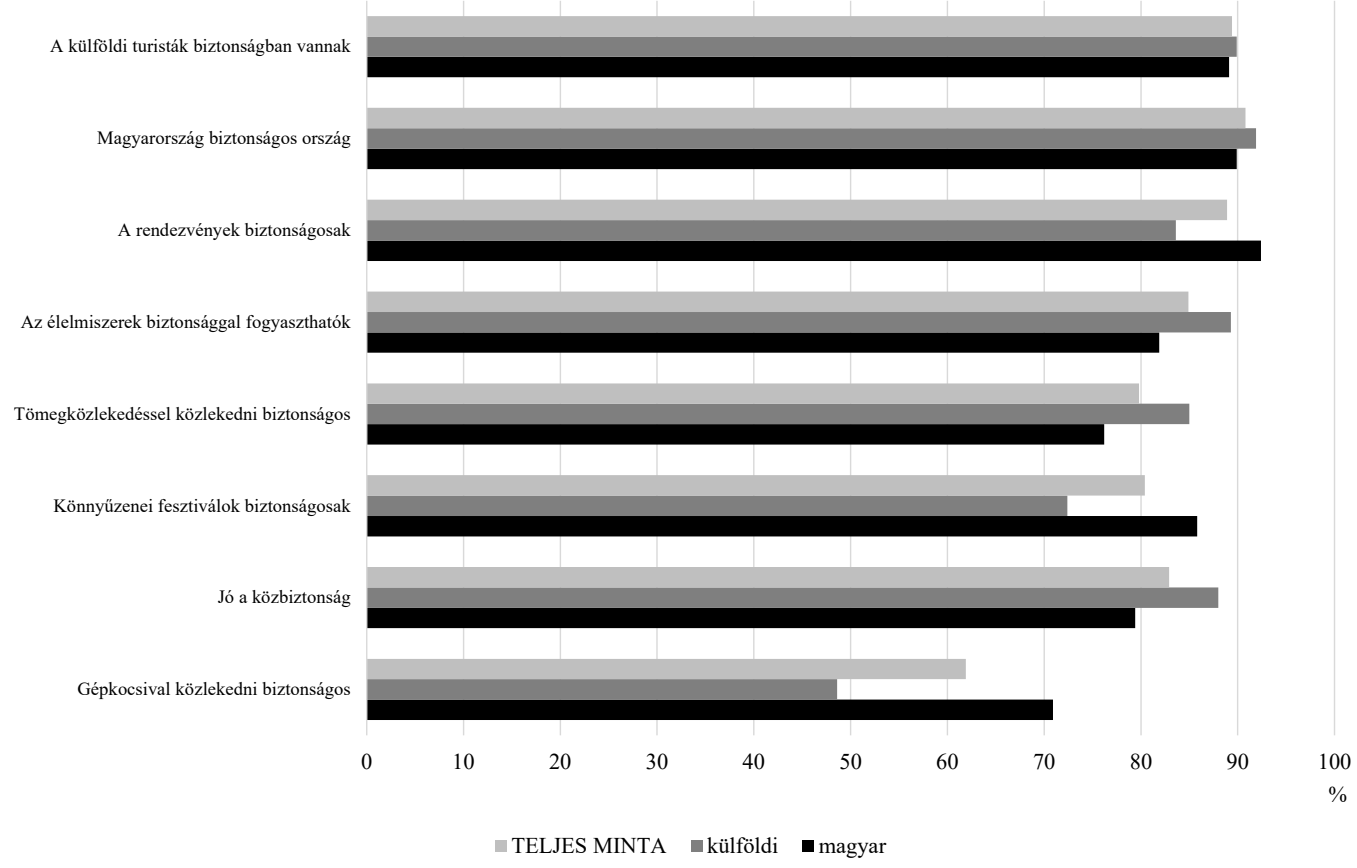

Forrás: saját számítás, MTÜ-Századvég kutatás (2018) alapján 
ezek az események, amikor úticélt választanak, és csak ötödük adta azt a választ, hogy nagyban befolyásolják. Az eredmények azt mutatják, hogy a biztonság még mindig fontos szempont, azonban a békésebb időszakokban háttérbe szorult. A terrorcselekmények utáni biztonsági intézkedések hatására 2018-ra a bizalom és a szubjektív biztonságérzet visszaállt az európai turizmusban.

A terrorcselekmények és az utazási cél kiválasztásának esetében hasonló összefüggések mutatkoztak egyes szociodemográfiai jellemzók szerint. A magyarok, azon belül is a 18 év alatti gyermekkel egy családban élők, nagyobb arányban válaszolták, hogy valamilyen mértékben befolyásolják őket a terroresemények (inkább befolyásol - 21,9\%; nagyon befolyásol - 27,3\%). A nóket jobban befolyásolja (inkább befolyásol - 24,3\%; nagyon befolyásol - 22,8\%), mint a férfiakat (inkább befolyásol - 19,5\%; nagyon befolyásol - 18,4\%).

A turizmusbiztonság problematikája rendkívül sokrétû, a természeti katasztrófáktól a pénzügyi folyamatokon és a terrorizmuson át egészen a szálláshely-szolgáltatás, a környezet, az élelmiszerek, az egészség vagy a közlekedés biztonságáig terjed. Ezeket a tényezóket figyelembe véve együttesen és külön-külön is vizsgálják, hogy mely országokban mi jelent kockázatot az utazók számára. Kutatásunk során ezért mi is rákérdeztünk ezekre. Különbözô biztonsággal kapcsolatos állításokat fogalmaztunk meg, amelyek általánosságban az országhoz, az országban zajló rendezvényekhez és a könnyúzenei fesztiválokhoz kapcsolódnak. A válaszadásnál a megkérdezetteknek egy négyfokú skálán kellett értékelniük, hogy mennyire értenek egyet az adott állítással.

A grafikon az állítással egyetértők (inkább egyet ért (3) és teljes mértékben egyet ért (4)) százalékos arányát mutatja a külföldi-magyar megoszlásban és a teljes mintán belül (4. ábra).

Az ország általánosan vett biztonságával, valamint a külföldi turisták személyi biztonságával kapcsolatosan egyöntetúen pozitív a vélekedés a hazai és külföldi válaszolók körében egyaránt. A külföldiek a magyarországi közbiztonságot, valamint az élelmiszerbiztonságot és a tömegközlekedés biztonságát pozitívabban értékelték, míg a rendezvények és a gépjármúvel történő közúti közlekedés biztonságát negatívabban.

\section{5. Összegzés}

A geopolitikai helyzet, a bekövetkező események, valamint a különböző helyzetkezelési módok (marketing kampányok, biztonsági intézkedések) külön-külön és együttesen is jelentôs hatást gyakorolnak az érintett terület turizmusára. A biztonság továbbra is főszerepet játszik az utazási döntések meghozatalánál - amit empirikus kutatásunk alátámasztott - és a jövőben várhatóan még inkább felértékelődik. A 2015-2016-ban történt terrortámadások átmenetileg az európai turizmus gyengüléséhez vezettek, mellyel egyidejúleg és ezzel öszszefüggésben a turisztikai desztinációk regionális átrendeződése is megfigyelhető volt 2015-2018 között. Míg korábban inkább Európa nyugati és északi országainak a látogatottsága növekedett, 2015-re a biztonságosabbnak tekintett Közép- és KeletEurópa megelőzte Nyugat-Európát az odalátogató turisták számának növekedésében. 2018-ban a biztonság szerepe még mindig a kiemelten fontos szempontok között szerepelt, azonban a biztonságos országokban - mint például Magyarország - egyre inkább előtérbe kerülnek azok a hagyományos desztinációválasztási értékek, mint a kultúra, a történelem, a látnivalók, valamint az ár és a gasztronómia.

A hozzánk látogató turisták és a hazai fesztiválok, rendezvények résztvevôinek véleménye szerint Magyarország nemcsak biztonságos úticél, hanem méltó versenytársa is a többi európai országnak a kulturális örökség, a gasztronómia és a fesztiválturizmus terén. Felmérésünk eredményei szerint Magyarország a fesztiválok, a biztonság, az ár és a természet említése esetén listavezető az országok között. A különböző rendezvények látogatóinak turizmusbiztonsággal kapcsolatos attitúdjei között statisztikailag is igazolható összefüggések figyelhetőek meg, amelyek a szociodemográfiai jellemzők mentén rajzolódnak ki. A kor, a nem, az iskolai végzettség, a kiskorú gyermeket neveló családos, valamint belföldi vagy külföldi változók mentén figyelhetôk meg véleménykülönbségek. A Magyarországon élő, idősebb, családos, kiskorú gyermeket nevelők, valamint a nők Magyarország biztonságosságát pozitívabban, míg Európa biztonsági helyzetének elmúlt 5-10 éves alakulását negatívabban ítélik meg, és az erőszakos cselekmények jobban befolyásolják őket a desztinációválasztásban. Az Európában bekövetkezett terrorcselekmények az úticél kiválasztásakor iskolai végzettség szerint az egyetemi tanulmányokat végzőket befolyásolják a legkevésbé és a szakiskolai végzettséggel rendelkezőket a leginkább.

A turizmus biztonságát meghatározó egyéb tényezőkkel kapcsolatosan - mint például az élelmiszerek, az egészség, a közbiztonság és a közlekedés biztonsága - a rendezvények és a turisztikailag népszerú helyek külföldi látogatóinak véleménye összességében pozitívabb, mint a magyaroké.

A külföldiek a rendezvények és a gépjármúvel történő közúti közlekedés biztonságát értékelték a magyar válaszadóknál negatívabban. 
A biztonságos országkép kialakítása sokat számít a desztinációválasztásnál (PÉTER 2017, MARTON et al. 2018). A közösségi média felerősödött szerepe a prekoncepciók alakításában és a megtapasztalt biztonság hírének terjesztésében szintén erős hatást gyakorol a desztináció kiválasztására az utazások tervezése során. A turista nem mond le az utazásról, csak más desztinációt választ. Az eredmények alapján elmondható, hogy Magyarország és Budapest biztonságos desztinációk, azonban az utazási döntés pozitív befolyásolása érdekében rendkívül fontos ennek kommunikációja a turisták felé (WILK 2017).

\section{Felhasznált irodalom}

BAYRAMOV, E. - AGÁRDI I. (2018): Az észlelt kockázat utazási szándékra gyakorolt hatása konfliktusövezetekben: elméleti keretmodell. Turizmus Bulletin. 18(4). pp. 14-22.

BESENYŐ, J. (2017a): Low-cost attacks, unnoticable plots? Overview on the economical character of current terrorism. Strategic Impact. 62(1). pp. 83-100.

BESENYŐ, J. (2017b): Inferno Terror: Forest Fires as the New Form of Terrorism. Terrorism and Political Violence. 31(6). pp. 1229-1241.

BOROS L. (2017): A közterek átalakulása és a turizmus. In: Régi T. - Rátz T. - Michalkó G. (szerk.): Turizmus és transzformáció. Turizmus Akadémia (8). Kodolányi János Főiskola, MTA CSFK Földrajztudományi Intézet, Magyar Földrajzi Társaság. Orosháza, Budapest. pp. 131-149.

BRYMAN, A. (2015): Social Research Methods. Oxford University Press.

DUDÁS, G. - BOROS, L. - VIDA, GY. (2017): Comparing the temporal changes of airfares on online travel agency websites and metasearch engines. Tourism. 65(2). pp. 187-203.

JÁSZBERÉNYI M. (2016): Fesztiválturizmus. Akadémiai Kiadó, Budapest.

MARTON ZS. - KELLER K. - BIRKNER Z. (2018) A turizmusbiztonság hatása a desztináció imázsra. In: Józsa L. - Korcsmáros E. - Seres H. E. (szerk.): A hatékony marketing. EMOK 2018 Nemzetközi Tudományos Konferencia. Konferenciakötet. pp. 312-327.
MICHALKÓ G. (2007): A turizmuselmélet alapjai. Kodolányi János Fơiskola, Székesfehérvár.

PÉTER E. - NÉMETH K. - LELKÓNÉ T. I. (2018): Turizmusbiztonság, mint újonnan felmerülő fogyasztói igény. Turizmus Bulletin. 18(2). pp. 30-37.

PÉTER E. (2017): Dilemma: Menni vagy maradni? Változó igények, átalakuló pihenési szokások. In: Kiglics N. (szerk.): II. Turizmus és Biztonság Nemzetközi Tudományos Konferencia. Pannon Egyetem Nagykanizsai Kampusz. Tanulmánykötet. pp. 219-225.

PUSZTAI B. (2013): A turista jóllét forrása Találkozás az autentikus látnivalóval vagy igazi önmagunkkal. In: Michalkó G. - Rátz T. (szerk): Jó(l)lét és turizmus: utazók, termékek és desztinációk a boldogság és a boldogulás kontextusában. Kodolányi János Fóiskola, MTA CSFK Földrajztudományi Intézet, Magyar Földrajzi Társaság. Székesfehérvár-Budapest. pp. 13-21.

\section{Internetes források}

UNWTO (2017a): World Tourism Barometer. Volume 15. Advance Release January 2017. http:// marketintelligence.unwto.org/barometer/ january-2017-volume-15-advance-release, Letöltve: 2018. február 10.

UNWTO (2017b): World Tourism Barometer. Volume 15. October 2017. http://cf.cdn.unwto.org/sites/ all/files/pdf/unwto_barom17_05_october_ excerpt_.pdf, Letöltve: 2018. február 10.

UNWTO (2018): World Tourism Barometer Statistical Annex. Volume 16 Issue 4 October 2018. https:// www.e-unwto.org/toc/wtobarometereng/16/4, Letöltve: 2018. február 10.

WILK A. (2017): Magyarország, mint biztonságos desztináció. Biztonság és Turizmus - A Beutaztató Utazási Irodák szemszögéből. Konferencia előadás. OK-WORLD Travel Service, MUISZ - Beutaztató Bizottság. http://slideplayer.hu/ slide/12402892/, Letöltve: 2018. március 1.

WORLD ECONOMIC FORUM (2015): The Travel $\mathcal{E}$ Tourism Competitiveness Report. http:// www3.weforum.org/docs/TT15/WEF_Global_ Travel\&Tourism_Report_2015.pdf, Letöltve: 2019. november 6 . 